Mycologia, 101(4), 2009, pp. 503-511. DOI: 10.3852/07-180

(C) 2009 by The Mycological Society of America, Lawrence, KS 66044-8897

\title{
Molecular and morphological characterization of Dothiorella casuarini sp. nov. and other Botryosphaeriaceae with diplodia-like conidia
}

Juanita de Wet $^{1}$

Forestry and Agricultural Biotechnology Institute (FABI), Department of Microbiology and Plant Pathology, University of Pretoria, Pretoria 0002, South Africa

Bernard Slippers

Forestry and Agricultural Biotechnology Institute (FABI) and Department of Genetics, University of Pretoria, South Africa

Oliver Preisig

Forestry and Agricultural Biotechnology Institute (FABI)

Brenda D. Wingfield

Forestry and Agricultural Biotechnology Institute (FABI) and Department of Genetics, University of Pretoria, South Africa

Panaghiotis Tsopelas NAGREF-Institute of Mediterranean Forest Ecosystems, Terma Alkmanos, Athens, Greece

Michael J. Wingfield

Forestry and Agricultural Biotechnology Institute (FABI)

Abstract: After recent changes to the taxonomy of the Botryosphaeriaceae species with diplodia-like (= dark, ovoid, often pigmented) conidia are considered to belong to at least three genera including Diplodia, Lasiodiplodia and Dothiorella. In a recent molecular phylogenetic study it became apparent that two groups of isolates with diplodia-like conidia required taxonomic revision. One group of isolates originated from Cupressus sempervirens in Greece and Cyprus and had been identified as $D$. pinea f. sp. cupressi based on morphological characteristics. The other isolates originated from a Casuarina sp. in Australia and were superficially similar to those in the first group based on their morphologically similar diplodia-like conidia. The aim of this study was to resolve the taxonomy of these two groups of isolates by combining the information from the multiple gene genealogies with morphological characters. The results showed that the isolates from C. sempervirens in Greece and Cyprus represent D. cupressi. The isolates from Casuarina in Australia belong to the more distantly related genus Dothiorella and represent a distinct species that is described here as Do. casuarini sp. nov.

Accepted for publication 30 January 2009

${ }^{1}$ Corresponding author. E-mail: juanita.dewet@fabi.up.ac.za
Key words: Botryosphaeriaceae, Diplodia, Dothiorella

\section{INTRODUCTION}

Species of the Botryosphaeriaceae represent both pathogens and saprophytes of woody and nonwoody plants (Slippers and Wingfield 2007). Some well known species include the conifer pathogen Diplodia pinea (Desm.) J. Kickx f. (Eldridge 1961, Swart and Wingfield 1991), the fruit tree pathogen $D$. seriata de Not. (Phillips et al 2007, Slippers et al 2007), the blue stain-associated Lasiodiplodia theobromae (Pat.) Griffon \& Maubl. (Mohali et al 2005) and Botryosphaeria dothidea (Moug. Fr.) Ces. \& de Not (Slippers et al 2004a). In recent years analyses of DNA sequence data have had a significant influence on the taxonomy of the Botryosphaeriaceae resulting in the description of 10 generic lineages and various cryptic species (e.g. de Wet et al 2003, Crous et al 2006). Of particular relevance to this study is the fact that various investigations have shown that genera Diplodia, Lasiodiplodia and Dothiorella, all of which have anamorphs characterized by dark, ovoid, often pigmented conidia (diplodia-like) and have been regarded as synonyms (Denman et al 2000), are phylogenetically distinct (Phillips et al 2005, Crous et al 2006, de Wet et al 2008).

Diplodia and Lasiodiplodia are well characterized genera of the Botryosphaeriaceae, but Dothiorella has been resurrected only recently as an anamorph genus in this family (Phillips et al 2005). Species of Dothiorella are morphologically most similar to those of Diplodia. However Dothiorella conidia turn brown and 1-septate while still in the pycnidium and sometimes even when they are still attached to the conidiogenous cells. In contrast those of Diplodia typically become dark and septate only after discharge from the pycnidium. Furthermore in Dothiorella percurrent proliferation of the conidiogenous cells is extremely rare, while this form of conidium development is common in Diplodia. Of note, based on phylogenetic inference, Dothiorella spp. are more closely related to Neofusicoccum spp. with hyaline conidia than they are to other genera with Diplodialike conidia (Phillips et al 2005).

Dothiorella is currently represented by four species, namely Do. pyrenophora Sacc., Do. sarmentorum A.J.L. Phillips, Alves \& Luque, Do. iberica A.J.L. Phillips, 
Luque \& Alves and Do. viticola A.J.L. Phillips \& Luque. Dothiorella pyrenophora is the type species of Dothiorella having conidia that are brown and 1septate while inside the pycnidial cavity and often still attached to the conidiogenous cells (Crous and Palm 1999, Phillips et al 2005). Dothiorella sarmentorum has been reported from Malus, Ulmus, Pyrus, Prunus and Menispermum and probably has worldwide distribution (Phillips et al 2005). Dothiorella iberica is known from Quercus and Malus only in Italy and Spain (Phillips et al 2005) and Do. viticola occurs on Vitis vinifera in South Africa and Spain (Luque et al 2005).

In a molecular phylogenetic study (de Wet et al 2008) it became apparent that two groups of isolates require taxonomic revision. Both had superficially similar diplodia-like conidia. The one set of isolates are from Cupressus sempervirens in Greece and Cyprus, of which those from Greece had been identified as $D$. pinea f.sp cupressi based only on morphology (Xenopoulos and Tsopelas 2000). The other group of isolates originated from Casuarina in Canberra, Australia, and appeared to represent an undescribed Dothiorella species. The aim of this study was to combine molecular phylogenetic data with morphological characters to characterize these isolates.

\section{MATERIALS AND METHODS}

Fungal isolates and morphological characterization.-A collection of 11 isolates with diplodia-like conidia were characterized (TABLE I). Sequence data for various Botryosphaeriaceae not generated in this study were obtained from GenBank (TABLE I). All isolates were accessed from the Culture Collection (CMW) of the Tree Protection Cooperative Programme (TPCP), Forestry and Agricultural Biotechnology Institute (FABI), University of Pretoria, South Africa. Representative isolates from this study also have been deposited in the Culture Collection of the Centraalbureau voor Schimmelcultures (CBS), Utrecht, Netherlands.

Isolates were transferred to $2 \%$ water agar (WA) (Biolab Diagnostics, Midrand, South Africa), to which a few sterile pine needles had been placed on the agar surface to induce sporulation, and incubated at $25 \mathrm{C}$ in constant light. Single conidial isolates were generated by breaking pycnidia that were formed on the pine needles, spreading the conidia and letting them germinate. A single, germinating conidium was transferred and grown on $2 \%$ malt extract agar (MEA) (Biolab Diagnostics, Midrand, South Africa) at 25 C. All cultures were stored at $4 \mathrm{C}$ for further study.

Fruiting structures were sectioned by hand and mounted in clear lactic acid for morphological characterization. Morphological observations were made and images were recorded with a Zeiss Axioskop light microscope and Axiocam digital camera (Carl Zeiss, Germany). Growth rate and colony morphology of the isolates were determined on
$2 \%$ MEA at 25 C. Color descriptions of cultures, mycelium and conidia were made according to Rayner (1970).

DNA extractions. - DNA was extracted (Raeder and Broda 1985) from the freeze-dried mycelium of the 11 single conidial isolates (TABLE I). Isolates were grown in $500 \mu \mathrm{L}$ $2 \%$ malt extract (ME) (Biolab Diagnostics, Midrand, South Africa) broth in $1.5 \mathrm{~mL}$ Eppendorf tubes, incubated at $25 \mathrm{C}$ 1 wk before DNA extraction. The broth was removed by centrifugation (20 min at $13000 \mathrm{rpm}$ ) washed with distilled water and freeze-dried.

DNA amplification and sequencing.-Part of the elongation factor $1 \alpha(\mathrm{EF}-1 \alpha)$ (Carbone and Kohn 1999) gene was amplified for 11 diplodia-like isolates (TABLE I) with primers and conditions as described by de Wet et al $(2000,2003)$. The ITS regions of the rDNA operon (White et al 1990) for four of these isolates (TABLE I) also were amplified, while those of the rest were obtained from a study by de Wet et al (2008). PCR products were viewed on a $1 \%$ agarose gel containing ethidium bromide with UV illumination. The PCR products were purified with the Roche High Pure PCR product purification kit (Roche Diagnostics, Germany). Both DNA strands were sequenced with the ABI PRISM ${ }^{\circledR}$ BigDye $^{\circledR}$ Terminator v3.1 Cycle Sequencing kit and an ABI PRISM ${ }^{\circledR} 3100$ DNA sequencer (Applied Biosystems, Foster City, California). All reactions were done with protocols recommended by the manufacturers. All tsequence data were processed with Sequence Navigator 1.0.1 (Perkin Elmer) and aligned with MAFFT 5 (Katoh et al 2005).

Phylogenetic analyses._- ITS and EF-1 $\alpha$ sequence data were combined after a partition homogeneity test to determine whether there is congruency between the different phylogenies using PAUP* (Swofford 2002), and the combined dataset was submitted to TreeBase (SN3866). The homogeneity test was based on strict heuristic searches with a treebisection reconnection (TBR) branch swapping algorithm and 1000 replicates. Parsimony, distance (NJ) and Bayesian analyses were applied to the combined dataset. Introns occurring in the partial EF- $1 \alpha$ gene sequences were included in the phylogenetic analyses. All characters were treated as unordered and having equal weight. The phylogenetic signal (G1) of the datasets was determined with PAUP* and compared with critical values (Hillis and Huelsenbeck 1992) at the 0.01 and 0.05 confidence levels.

Parsimony was based on strict heuristic searches with a tree-bisection reconnection (TBR) branch swapping algorithm, stepwise addition and collapse of branches if maximum length is zero. Neighbor joining distance analysis was done in PAUP* with the most appropriate model of DNA substitution as determined with MODELTEST 3.5 (Posada and Crandall 1998). Bayesian analysis with MrBayes 3.1.2 (Ronquist and Huelsenbeck 2003) implementing the Markov chain Monte Carlo (MCMC) technique and the parameters predetermined with MODELTEST 3.5 was performed. Four simultaneous Markov chains were run from random starting trees 500000 generations, and trees were sampled every 100 generations. The first 700 of 5001 trees generated were discarded as burn-in. The Bayesian 
analysis was repeated to test the independence of the results from topological priors. Bootstrap support was determined after 1000 replications and only groups with frequencies $>50 \%$ were retained. All phylogenetic trees were viewed in TreeView and monophyletically rooted to Mycosphaerella spp. as outgroups (M. konae Crous, Joanne E. Taylor \& M.E. Palm: ITS $=$ AY260085, EF-1 $\alpha=$ AY752185; and M. citri Whiteside: ITS $=$ AY752145, EF-1 $\alpha=$ AY752179).

\section{RESULTS}

Phylogenetic analyses. - A total of 260 bp of the EF-1 $\alpha$ gene were amplified and sequenced for 11 diplodialike isolates (TABLE I). For four of these isolates $540 \mathrm{bp}$ of the rDNA operon including the ITS1, ITS2 and 5.8S subunit also were amplified and sequenced (TABLE I). GenBank sequences of 26 isolates, representing Diplodia, Lasiodiplodia, Dothiorella, Botryosphaeria and Neofusicoccum, were added for comparative purposes (TABLE I). A partition homogeneity test showed that no significant conflict exists between the phylogenies of the rDNA and EF- $1 \alpha$ sequences $(P$ $=0.1)$. The $\mathrm{G} 1$ value $(\mathrm{G} 1=-0.33)$ was lower than the predicted critical values at both the 95\% ( $P=$ $-0.08)$ and $99 \%(P=-0.09)$ confidence levels, implying a strong phylogenetic signal. The combined dataset contained 808 characters of which 327 characters were constant, 71 were variable and 410 were variable, parsimony informative characters. The dataset had a tree length of 1113, a consistency index (CI) of 0.73 , a retention index (RI) of 0.92 and a homoplasy index (HI) of 0.27 . These indices measure the level of homoplasy, which is an indication of the reliability of the parsimonious cladograms. MODELTEST 3.5 tested 56 models and predicted the TamuraNei model with unequal frequencies $(\operatorname{TrN})$ and a gamma distribution shape parameter $(G)$ as the most appropriate model of DNA substitution.

Two major clades were observed after analyses of the combined dataset (FIG. 1) and these results were confirmed when analyses were done on the two datasets independently. One major clade represented Diplodia and Lasiodiplodia and the other Botryosphaeria, Dothiorella and Neofusicoccum. The Diplodia/Lasiodiplodia clade comprised seven subclades, namely D. cupressi, D. mutila, D. scrobiculata, D. pinea, $D$. seriata, $L$. theobromae and $D$. porosum van Niekerk \& Crous. The Dothiorella/Neofusicoccum/Botryosphaeria clade also consisted of seven subclades including Do. sarmentorum, Do. iberica, an undescribed Dothiorella species, N. eucalyptorum, $N$. luteum, $N$. ribis and B. dothidea.

The isolates from $C$. sempervirens from Greece and Cyprus grouped with D. cupressi from Israel. While isolates from Casuarina in Australia grouped in a distinct clade representing an undescribed Dothiorella species, with strong bootstrap and Bayesian posterior probability support (100\% and 1.0 respectively). Support for the undescribed Dothiorella species as a distinct member of genus Dothiorella also was provided when the two datasets were analyzed separately as well as when the most variable and ambiguously aligned regions in the datasets were excluded (bases 77-144 in the ITS dataset and bases 1-30 and 153-230 of the EF-1 $\alpha$ dataset).

\section{TAXONOMY}

Results of the phylogenetic and morphological analyses provide robust evidence to support treatment of the isolates from a Casuarina sp. as a discrete taxon for which this description is provided:

Dothiorella casuarini J. de Wet, Slippers \& M.J. Wingfield anam. sp. nov. FIGS. 2-7 MB510856

Etymology. named for Casuarina, the host from which the fungus was isolated.

Margines coloniarum irregulariter rosulatae. Mycelium cum seriebis tumorum hyphorum chlamydosporas semblantium. Conidiomata pycnidialia, nigra, globosa. Cellulae conidiogenae cellulis parietum pycnidiorum proxime portatae, holoblasticae, hyalinae, subcylindricae, in plano eodem in concretionibus periclinalibus proliferantes, raro percurrente proliferantes bis vel ter indistincte annulatae. Conidia 22-38 × 8-13.5 $\mu \mathrm{m}$ (mediocriter $27.1 \times 10.8 \mu \mathrm{m}$ ), primo non septata hyalina subcylindrica, dum etiam in pycnidio brunnescentia vel atrobrunnescentia, uniseptata raro 2-3 septata, ellipsoidea vel ovoidea, raro anguste ellipsoidea, apice late rotundata, basi truncata.

Cultures smooth to fluffy, pale greenish gray to greenish gray from above, becoming lighter or white around the edges, light bluish of sky gray from below, colony margins irregular, rosette-like. Mycelium thick walled, branched, septate, melanized light to dark brown, with strings of dark brown chlamydospore-like hyphal swellings. Conidiomata pycnidia, black, globose, ostiole central, solitary, scattered and immersed in water agar, few on pine needles supplied as substrate. Conidiophores absent. Conidiogenous cells emerging directly from cells lining the pycnidial cavity, holoblastic, hyaline, smooth-walled, subcylindrical, determinate or indeterminate and proliferating at the same level resulting in periclinal thickening, very rarely proliferating percurrently to produce two or three indistinct annellations. Conidia (22-)23-31(-38) × (8-)9-12 $(-13.5) \mu \mathrm{m}$ (av. 60 conidia $=27.1 \times 10.8 \mu \mathrm{m})$, initially aseptate and hyaline, becoming brown to dark brown or sepia and 1-septate within the pycnidium, rarely 2-3 septate, ellipsoid to ovoid, rarely narrow ellipsoid, as obtuse apex and truncate base. 
Table I. Diplodia and Dothiorella isolates included in this study as well as other members of the Botryosphaeriaceae used for comparative purposes

\begin{tabular}{|c|c|c|c|c|c|c|}
\hline \multirow[b]{2}{*}{ Isolates $^{\mathrm{a}}$} & \multirow[b]{2}{*}{ Species } & \multirow[b]{2}{*}{ Origin } & \multirow[b]{2}{*}{ Host } & \multirow[b]{2}{*}{ Reference/collector ${ }^{b}$} & \multicolumn{2}{|c|}{$\begin{array}{c}\text { GenBank accession } \\
\text { numbers }\end{array}$} \\
\hline & & & & & ITS & EF-1 $\alpha$ \\
\hline CMW19954 & D. cupressi & Greece & $\begin{array}{l}\text { Cupressus } \\
\text { sempervirens }\end{array}$ & $\begin{array}{l}\text { P. Tsopelas (SH-1/ } \\
\text { CBS120691) }\end{array}$ & DQ846775 & DQ875334 \\
\hline CMW19955 & D. cupressi & Greece & $\begin{array}{l}\text { Cupressus } \\
\text { sempervirens }\end{array}$ & $\begin{array}{l}\text { P. Tsopelas (SH-2/ } \\
\text { CBS120692) }\end{array}$ & DQ846776 & DQ875335 \\
\hline CMW19956 & D. cupressi & Cyprus & $\begin{array}{l}\text { Cupressus } \\
\text { sempervirens }\end{array}$ & $\begin{array}{l}\text { P. Tsopelas (SH-4/ } \\
\text { CBS120693) }\end{array}$ & DQ846777 & DQ875336 \\
\hline CMW19957 & D. cupressi & Cyprus & $\begin{array}{l}\text { Cupressus } \\
\text { sempervirens }\end{array}$ & $\begin{array}{l}\text { P. Tsopelas (SH-7/ } \\
\text { CBS121027) }\end{array}$ & DQ846779 & DQ875338 \\
\hline CMW4854 & $\begin{array}{l}\text { Dothiorella } \\
\text { casuarini }\end{array}$ & Australia & Casuarina sp. & MJ. Wingfield & EF107752 & EF107758 \\
\hline $\begin{array}{l}\text { CMW4855 } \\
\quad(\text { CBS120688) }\end{array}$ & $\begin{array}{l}\text { Dothiorella } \\
\text { casuarini }\end{array}$ & Australia & Casuarina sp. & MJ. Wingfield & DQ846773 & DQ875331 \\
\hline $\begin{array}{l}\text { CMW4856 } \\
\quad(\text { CBS120689) }\end{array}$ & $\begin{array}{l}\text { Dothiorella } \\
\text { casuarini }\end{array}$ & Australia & Casuarina sp. & MJ. Wingfield & DQ846772 & DQ875332 \\
\hline $\begin{array}{l}\text { CMW4857 } \\
\quad(\text { CBS120690) }\end{array}$ & $\begin{array}{l}\text { Dothiorella } \\
\text { casuarini }\end{array}$ & Australia & Casuarina sp. & MJ. Wingfield & DQ846774 & DQ875333 \\
\hline CMW4858 & $\begin{array}{l}\text { Dothiorella } \\
\text { casuarini }\end{array}$ & Australia & Casuarina sp. & MJ. Wingfield & EF107753 & EF107759 \\
\hline CMW1182 & D. cupressi & Israel & C. sempervirens & $\begin{array}{l}\text { W. Swart (Swart et al } \\
\text { 1993) }\end{array}$ & EU220433 & EU220487 \\
\hline CMW1183 & D. cupressi & Israel & C. sempervirens & $\begin{array}{l}\text { W. Swart (Swart et al } \\
\text { 1993) }\end{array}$ & EU220434 & EU220488 \\
\hline CBS168.87 & D. cupressi & Israel & C. sempervirens & Alves et al 2006 & DQ458893 & DQ458878 \\
\hline CMW190 & D. pinea (A) & United States & Pinus resinosa & $\begin{array}{l}\text { Palmer et al 1987, De } \\
\text { Wet et al } 2000 \text { and } \\
2003\end{array}$ & AY253290 & AY624251 \\
\hline CMW4876 & D. pinea $(\mathrm{C})$ & Indonesia & P. patula & $\begin{array}{l}\text { De Wet et al } 2000 \text { and } \\
2003\end{array}$ & AY253294 & AY624252 \\
\hline CMW5870 & D. scrobiculata & California & P. radiata & De Wet et al 2003 & AY623704 & AY624254 \\
\hline CMW4900 & D. scrobiculata & Mexico & P. greggii & De Wet et al 2003 & AY623705 & AY624255 \\
\hline CMW189 & D. scrobiculata & USA & P. banksiana & $\begin{array}{l}\text { Palmer et al 1987, De } \\
\text { Wet et al } 2000 \text { and } \\
2003\end{array}$ & AY253292 & AY624253 \\
\hline CMW8230 & D. seriata & Canada & Picea glauca & De Wet et al 2003 & AY972104 & DQ280418 \\
\hline CMW8232 & D. seriata & South Africa & Malus domestica & De Wet et al 2003 & AY972105 & DQ280419 \\
\hline CMW9074 & $\begin{array}{c}\text { Lasiodiplodia } \\
\text { theobromae }\end{array}$ & Mexico & Pinus sp. & Slippers et al 2004a & AY236952 & AY236901 \\
\hline CMW10130 & L. theobromae & Uganda & Vitex doniana & Slippers et al 2004a & AY236951 & AY236900 \\
\hline CMW7060 & D. mutila & Netherlands & Fraxinus excelsior & Slippers et al 2004a & AY236955 & AY236904 \\
\hline CMW7776 & D. mutila & Italy & Fraxinus excelsior & r Slippers et al 2004a & AY972106 & DQ280420 \\
\hline CMW7999 & B. dothidea & Switzerland & Ostrya sp. & Slippers et al 2004a & AY236948 & AY236897 \\
\hline CMW8000 & B. dothidea & Switzerland & Prunus sp. & Slippers et al 2004a & AY236949 & AY236898 \\
\hline CBS110574 & D. porosum & & Vitis vinifera & Van Niekerk et al 2004 & 4 AY343378 & AY343340 \\
\hline CBS110496 & D. porosum & South Africa & Vitis vinifera & Van Niekerk et al 2004 & 4 AY343379 & AY343339 \\
\hline IMI63581b & Do. sarmentorum & England & Ulmus sp. & Phillips et al 2005 & AY573212 & AY573223 \\
\hline CBS115038 & Do. sarmentorum & Netherlands & M. pumila & Phillips et al 2005 & AY573206 & AY573235 \\
\hline CBS115041 & Do. iberica & Spain & Quercus ilex & Phillips et al 2005 & AY573202 & AY573222 \\
\hline CBS115035 & Do. iberica & Spain & Quercus ilex & Phillips et al 2005 & AY573213 & AY573228 \\
\hline CBS121117 & Do. viticola & South Africa & $\vec{V}$. vinifera & Damm et al 2007 & EF445361 & EF445394 \\
\hline CBS121118 & Do. viticola & South Africa & V. vinifera & Damm et al 2007 & EF445360 & EF445393 \\
\hline CMW7772 & $\begin{array}{l}\text { Neofusicoccum } \\
\quad \text { ribis }\end{array}$ & $\begin{array}{l}\text { New York, } \\
\text { USA }\end{array}$ & Ribes sp. & Slippers et al 2004a & AY236935 & AY236877 \\
\hline CMW7773 & $\begin{array}{l}\text { Neofusicoccum } \\
\text { ribis }\end{array}$ & $\begin{array}{l}\text { New York, } \\
\text { USA }\end{array}$ & Ribes sp. & Slippers et al 2004a & AY236936 & AY236878 \\
\hline
\end{tabular}




\begin{tabular}{|c|c|c|c|c|c|c|}
\hline \multirow[b]{2}{*}{ Isolates $^{\mathrm{a}}$} & \multirow[b]{2}{*}{ Species } & \multirow[b]{2}{*}{ Origin } & \multirow[b]{2}{*}{ Host } & \multirow[b]{2}{*}{ Reference/collector ${ }^{\mathrm{b}}$} & \multicolumn{2}{|c|}{$\begin{array}{c}\text { GenBank accession } \\
\text { numbers }\end{array}$} \\
\hline & & & & & ITS & $\mathrm{EF}-1 \alpha$ \\
\hline ВОТ24 & N. eucalyptorum & South Africa & Eucalyptus sp. & Smith et al 2001 & AF283686 & AY339264 \\
\hline BOT16 & N. eucalyptorum & South Africa & Eucalyptus sp. & Smith et al 2001 & AF283687 & AY236892 \\
\hline CMW9076 & N. luteum & New Zealand & M. domestica & Slippers et al 2004b & AY236946 & AY339265 \\
\hline CMW10310 & N. luteum & Portugal & V. vinifera & Slippers et al 2004b & AY339259 & AY339267 \\
\hline
\end{tabular}

${ }^{a}$ CMW refers to the Culture Collection (CMW) of the Tree Protection Co-operative Programme (TPCP), Forestry and Agricultural Biotechnology Institute (FABI), University of Pretoria, South Africa.

${ }^{\mathrm{b}}$ Reference refers to publications where the same isolates were used and collector refers to the collector and isolation numbers of isolates not previously published.

${ }^{\mathrm{c}}$ Sequences for isolates in boldface were generated in the present study while the remainder were obtained from GenBank.

Known host. Casuarina sp.

Known geographical range. Canberra, Australia.

Cultures examined. AUSTRALIA: Canberra: Cotter River. On Casuarina sp., 2000, M.J. Wingfield (CMW4855/ CBS120688) in Herb. PREM59650 (HOLOTYPE). AUSTRALIA: Canberra: Cotter River. On Casuarina sp., 2000, M.J. Wingfield (CMW4856/CBS120689, CMW4857/ CBS120690, CMW4854, CMW4858) all in Herb. PREM59651， PREM59652， PREM59649， PREM59653 (PARATYPES).

\section{DISCUSSION}

The gene genealogy generated from ITS rDNA and partial EF- $1 \alpha$ sequence data, combined with morphological observations, provide robust evidence to justify the description of a set of diplodia-like isolates from Casuarina in Australia as the new species Dothiorella casuarini. This is the fifth species confirmed by DNA sequence data to be described in Dothiorella. All except the type species, Do. pyrenophora for which no cultures are available, are phylogenetically distinct. In contrast it would be very difficult to distinguish them based only on morphological characteristics because these often overlap and the more easily distinguishable teleomorphs are rare. This is a problem that is encountered increasingly commonly for fungi (Crous 2005) with the Botryosphaeriaceae providing an excellent example (Crous et al 2006).

Dothiorella spp. are distinguished from other anamorph genera of the Botryosphaeriaceae based on conidial morphology and DNA sequence comparisons (Luque et al 2005, Phillips et al 2005). In this regard Do. casuarini has conidia that are ellipsoid to ovoid, initially aseptate and hyaline turning brown to dark brown and 1-septate while still in the pycnidium. Conidia of this species are longer than those of $D o$. sarmentorum, Do. iberica and Do. viticola. It is also characterized by chlamydospore-like hyphal swellings, which frequently are observed but have not been reported in other Dothiorella spp. Furthermore Do. casuarini has obvious smooth to fluffy gray-green cultures with typical irregular, rosette-like borders.

No teleomorph structures have been observed for Do. casuarini. This is not unusual because sexual states are typically less common in the Botryosphaeriaceae than anamorph states. The known teleomorphs of other Dothiorella sp. were described as "Botryosphaeria" sarmentorum A.J.L. Phillips, Alves \& Luque, "Botryosphaeria" iberica A.J.L. Phillips, Luque \& Alves and "Botryosphaeria" viticola A.J.L. Phillips \& Luque (Phillips et al 2005). The teleomorph of Dothiorella has since been placed in genus Dothidotthia, but the above mentioned teleomorphs have not been formally renamed (Crous et al 2006). If a teleomorph were to be found for Do. casuarini this would be expected to have the characteristics of Dothidotthia.

Phylogenetic analyses of the ITS rDNA and partial EF-1 $\alpha$ sequence data, grouped a set of isolates from Greece and Cyprus with the ex-type cultures of $D$. cupressi from Israel. This fungus was described by Alves et al (2006) and was known previously as $D$. pinea f. sp. cupressi, the causal agent of a canker disease on Cupressus sempervirens in Israel (Solel et al 1987), South Africa (Linde et al 1997), Greece (Xenopoulos and Tsopelas 2000) and Tunisia (Intini and Panconesi 2005). This is the first report of the pathogen from C. sempervirens in Cyprus. Diplodia cupressi is phylogenetically most closely related to $B$. tsugae and D. mutila (Alves et al 2006) and clearly has no logical association with $D$. pinea. Diplodia cupress $i$ is also the name given to the pathogen found on Juniperus spp. previously identified as D. mutila (Alves et al 2006, de Wet et al 2008). 


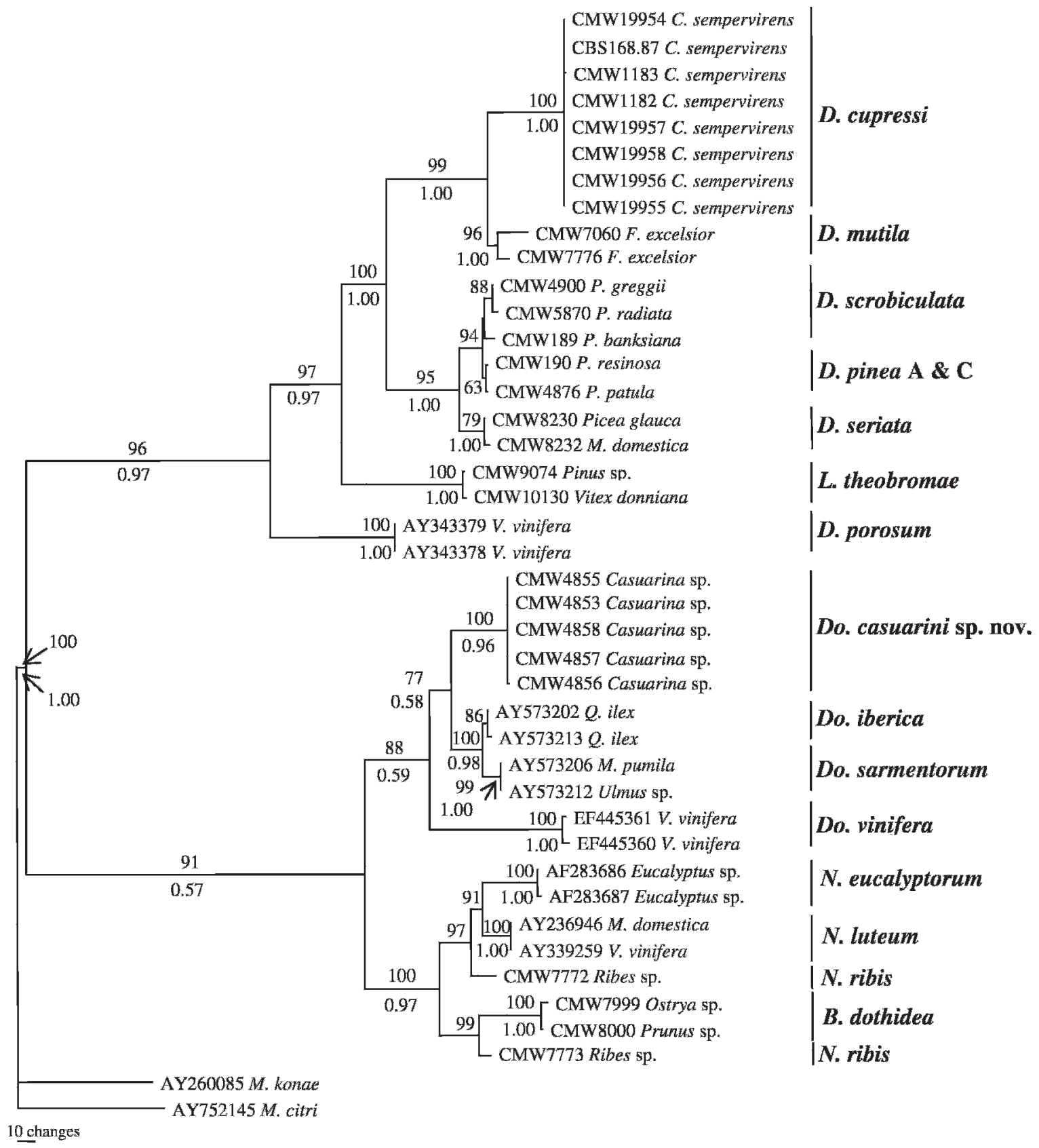

FIG. 1. Maximum parsimony phylogram constructed from the sequences of the rDNA operon (ITS regions and 5.8S ribosomal subunit) and partial elongation factor 1 alpha (EF-1 $\alpha$ ) based on strict heuristic searches with a tree-bisection reconnection (TBR) branch swapping algorithm, stepwise addition and collapse of branches if maximum length is zero with branch support values (maximum parsimony bootstrap proportions/Bayesian posterior probabilities). Bootstrap values were determined after 1000 replications in PAUP*. Only groups with frequencies $>50 \%$ were retained. The Bayesian posterior support values were determined with MrBayes 3.1.2 with the Tamura-Nei model and a gamma distribution shape parameter $(\mathrm{TrN}+\mathrm{G})$. The bar represents 10 changes.

Phylogenetic analyses in this study showed that $D$. cupressi is more closely related to species from hardwoods, such as D. mutila from Fraxinus, than to $D$. pinea. Of interest $D$. pinea also is more closely related to the hardwood-infecting species $D$. seriata than to other softwood-infecting species. Clearly distantly related hosts have been colonized by ancestors of these fungi. These host jumps (Slippers et al 2005), instead of co-evolution with the hosts, most likely contributed to the speciation of the taxa. These results also support a study by de Wet et al (2008) in which we showed that species of Diplodia 

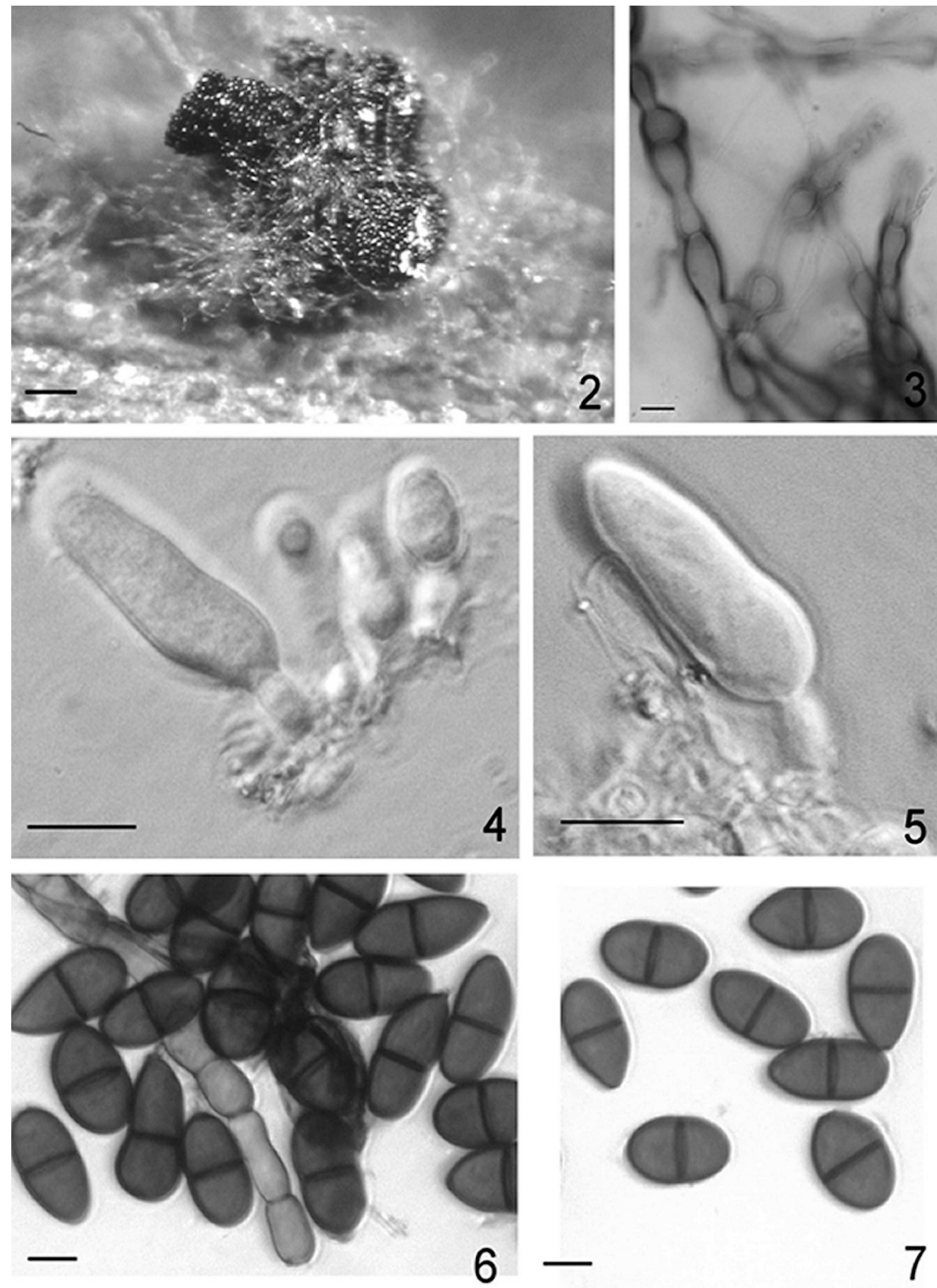

Figs. 2-7. Dothiorella casuarini sp. nov. 2. Pycnidium formed on a sterile pine needle in culture on water agar. 3. Pigmented chlamydospore-like hyphal cells in chains. 4-5. Conidiogenous cells and immature developing conidia. 6-7. Mature, septate, dark conidia. Bars $=10 \mu \mathrm{m}$. 
and Lasiodiplodia were common on both gymnosperms and angiosperms (D. seriata, D. porosum, L. theobromae). This was in contrast to species of Dothiorella, Neofusicoccum and Botryosphaeria that were almost all from angiosperms, which is the likely ancestral host group of the Botryosphaeriaceae (de Wet et al 2008).

Diplodia, Lasiodiplodia and Dothiorella all are morphologically similar members of the Botryosphaeriaceae. These genera have conidia that are similar in size and shape (ellipsoidal to ovoid), initially hyaline, but becoming pigmented with age, and sometimes septate. Isolates belonging to these three genera included in this study however could easily be assigned to these genera with multiple gene sequence comparisons. This underscores the importance of combining morphological and DNA sequence data when identifying and describing new species with diplodia-like characteristics (Denman et al 2000, de Wet et al 2003, Alves et al 2004, Pavlic et al 2004, Alves et al 2006).

Diplodia and Lasiodiplodia are clearly sister genera and it is not surprising that they share similar conidial morphology. Dothiorella however is more closely related to morphologically distinct genera such as Neofusicoccum and Botryosphaeria. The latter taxa have conidia that are mostly hyaline and fusoid and only rarely become pigmented, thus are very different from those of Dothiorella. Pigmented older conidia that are ovoid to ellipsoid thus represent a polyphyletic character, which has been lost or gained independently among the lineages of the Botryosphaeriaceae.

Results of this study confirm the value of generating multiple gene genealogies to resolve the status of species of the Botryosphaeriaceae with diplodia-like anamorphs. It has further shown that morphology or host association does not necessarily reflect the evolutionary history of the Botryosphaeriaceae genera. Much remains to be understood regarding the role of host association in shaping the diversity and distribution of species in this group of fungi. Studies considering conidial morphology and factors that influence this character based on a more complete taxon set are likely to reflect important aspects of the evolutionary histories for members of the Botryosphaeriaceae.

\section{ACKNOWLEDGMENTS}

We are grateful for the financial support of the National Research Foundation (NRF), members of the Tree Protection Co-operative Programme (TPCP) and the THRIP initiative of the Department of Trade and Industry (DTI), South Africa. We also thank Dr Hugh Glen for assistance in preparing the Latin diagnosis for the new species.

\section{LITERATURE CITED}

Alves A, Correia A, Luque J, Phillips JL. 2004. Botryosphaeria corticola sp. nov. on Quercus species, with notes and description of Botryosphaeria stevensii and its anamorph, Diplodia mutila. Mycologia 96:598-613.

,-- , Phillips JL. 2006. Multiple gene genealogies and morphological data support Diplodia cupressi sp. nov., previously recognized as $D$. pinea f.sp. cupressi, as a distinct species. Fungal Divers 23:1-15.

Carbone I, Kohn LM. 1999. A method for designing primer sets for speciation studies in filamentous ascomycetes. Mycologia 91:553-556.

Crous PW. 2005. Impact of molecular phylogenetics on the taxonomy and diagnostics of fungi. OEPP/EPPO Bulletin 35:47-51.

—, Palm ME. 1999. Reassessment of the anamorphs genera Botryodiplodia, Dothiorella and Fusicoccum. Sydowia 51:161-175.

— Slippers B, Wingfield MJ, Rheeder J, Marasas WFO, Phillips AJL, Burgess T, Barber P, Groenewald JZ. 2006. Phylogenetic lineages in the Botryosphaeriaceae. Stud Mycol 55:239-257.

Damm U, Crous PW, Fourie PH. 2007. Botryosphaeriaceae as potential pathogens of Prunus species in South Africa, with descriptions of Diplodia africana and Lasiodiplodia plurivora spp. nov. Mycologia 99:664-680.

Denman S, Crous PW, Taylor JE, Kang J-C, Pascoe I, Wingfield MJ. 2000. An overview of the taxonomic history of Botryosphaeria, and a re-evaluation of its anamorphs based on morphology and ITS rDNA phylogeny. Stud Mycol 45:129-140.

de Wet J, Burgess T, Slippers B, Preisig O, Wingfield BD, Wingfield MJ. 2003. Multiple gene genealogies and microsatellite markers reflect relationships between morphotypes of Sphaeropsis sapinea and distinguish a new species of Diplodia. Mycol Res 107:557-566.

— 2008. Phylogeny of the Botryosphaeriaceae reveals patterns of host association. Mol Phylogenet Evol 46: 116-126.

— Wingfield MJ, Coutinho TA, Wingfield BD. 2000. Characterization of Sphaeropsis sapinea isolates from South Africa, Mexico and Indonesia. Plant Dis 84:151156.

Eldridge KG. 1961. Significance of Diplodia pinea in plantations. Rev Appl Mycol 41:339.

Hillis DM, Huelsenbeck JP. 1992. Signal, noise and reliability in molecular phylogenetic analyses. J Hered 83:189-195.

Intini M, Panconesi A. 2005. First report of Diplodia canker of cypress caused by Diplodia pinea f.sp. cupressi on Mediterranean cypress in Tunisia. Plant Dis 89:1246.

Katoh K, Kuma K-I, Toh H, Miyata T. 2005. MAFFT 5: improvement in accuracy of multiple sequence alignment. Nucleic Acid Res 33:511-518.

Linde C, Kemp GHJ, Wingfield MJ. 1997. First report of Sphaeropsis canker on cypress in South Africa. Eur J Forest Path 27:173-177.

Luque J, Martos S, Phillips AJL. 2005. Botryosphaeria viticola 
sp. nov. on grapevines: a new species with a Dothiorella anamorph. Mycologia 97:1111-1121.

Mohali S, Burgess TI, Wingfield MJ. 2005. Diversity and host association of the tropical tree endophyte Lasiodiplodia theobromae revealed using simple sequence repeat markers. Forest Pathol 35:385-396.

Palmer MA, Stewart EL, Wingfield MJ. 1987. Variation among isolates of Sphaeropsis sapinea in the north central United States. Phytopathology 77:944-948.

Pavlic D, Slippers B, Coutinho TC, Gryzenhout M, Wingfield MJ. 2004. Lasiodiplodia gonubiensis sp. nov., a new Botryosphaeria anamorph from native Syzygium cordatum in South Africa. Stud Mycol 50:313-322.

Phillips AJL, Alves A, Correia A, Luque J. 2005. Two new species of Botryosphaeria with brown 1-septate ascospores and Dothiorella anamorphs. Mycologia 97:513529.

— Crous PW, Alves A. 2007. Diplodia seriata, the anamorph of "Botryosphaeria" obtusa. Fungal Divers 25:141-155.

Posada D, Crandall KA. 1998. MODELTEST: testing the model of DNA substitution. Bioinformatics 14:817-818.

Raeder U, Broda P. 1985. Rapid preparation of DNA from filamentous fungi. Lett Appl Microbiol 1:17-20.

Rayner RW. 1970. A mycological colour chart. Kew, Surrey, UK: CMI and British Mycological Society. 34 p.

Ronquist F, Huelsenbeck JP. 2003. MrBayes 3: Bayesian phylogenetic inference under mixed models. Bioinformatics 19:1572-1574.

Slippers B, Crous PW, Denman S, Coutinho TA, Wingfield BD, Wingfield MJ. 2004a. Combined multiple gene genealogies and phenotypic characters differentiate several species previously identified as Botryosphaeria dothidea. Mycologia 96:83-101.

, Fourie G, Crous PW, Coutinho TA, Wingfield BD, Wingfield MJ. 2004b. Multiple gene sequences delimit Botryosphaeria australis sp. nov. Mycologia 96:10301041.
Smit WA, Crous PW, Coutinho TA, Wingfield BD, Wingfield MJ. 2007. Taxonomy, phylogeny and identification of Botryosphaeriaceae associated with pome and stone fruit trees in South Africa and other regions of the world. Plant Pathol 56:128-139.

— Stenlid J, Wingfield MJ. 2005. Emerging pathogens: fungal host jumps following anthropogenic introduction. Trend Ecol Evol 20:420-421.

—_, Wingfield MJ. 2007. The Botryosphaeriaceae as endophytes and latent pathogens of woody plants: diversity, ecology and impact. Fung Biol Rev 21:90-106.

Smith H, Crous PW, Wingfield MJ, Coutinho TA, Wingfield BD. 2001. Botryosphaeria eucalyptorum sp. nov., a new species in the $B$. dothidea-complex on Eucalyptus in South Africa. Mycologia 93:277-285.

Solel Z, Madar Z, Kimchi M, Golan Y. 1987. Diplodia canker of cypress. Can J Plant Pathol 9:115-118.

Swart WJ, Wingfield MJ. 1991. Biology and control of Sphaeropsis sapinea on Pinus species in South Africa. Plant Dis 75:761-766.

- - - Grant WS. 1993. Comparison of Sphaeropsis sapinea and Sphaeropsis sapinea f.sp. cupressi. Mycol Res 97:1253-1260.

Swofford DL. 2002. PAUP*: phylogenetic analysis using parsimony (*and other methods). Version 4.0b10. Sunderland, Massachusetts: Sinauer Associates Inc. Publishers.

van Niekerk JM, Crous PW, Groenewald JZ, Fourie PH, Halleen F. 2004. DNA phylogeny, morphology and pathogenicity of Botryosphaeria species on grapevines. Mycologia 96:781-798.

White TJ, Bruns T, Lee S, Taylor J. 1990. Amplification and direct sequencing of fungal rRNA genes for phylogenetics. In: Innis MA, Gelfand DH, Sninsky JJ, White TJ, eds. PCR protocols: a guide to methods and applications. San Diego: Academic Press. p 315-322.

Xenopoulos S, Tsopelas P. 2000. Sphaeropsis canker, a new disease of cypress in Greece. Forest Path 30:121-126. 